\title{
Immunolocalization of Lymphocyte Subsets in the Testis and Epididymis of Roosters
}

\author{
Yukinori Yoshimura, Yoshiko Tamura, Jin Xi Liang and Toshikazu Okamoto \\ Graduate School of Biosphere Science, Higashi-Hiroshima 739-8528, Japan
}

\begin{abstract}
The goal of this study was to localize the $\mathrm{T}$ cell subsets and $\mathrm{B}$ cells in the testis and epididymis of roosters. Frozen sections of testis and epididymis were immunostained for $\mathrm{CD} 4, \mathrm{CD} 8$ and $\mathrm{Bu} 1$, which are the specific surface antigens of helper/inducer $\mathrm{T}$ cells, cytotoxic/suppressor $\mathrm{T}$ cells and B cells, respectively. Both CD4 + and CD8 $+\mathrm{T}$ cells were located in the interstitial tissues of testis. In the epididymis many CD4 + and CD $8+\mathrm{T}$ cells were localized in the subepithelial layer (subepithelial stroma and fibromuscular layer) of efferent ductules and epididymal duct. Both $\mathrm{T}$ cell subsets were also distributed in the epididymal interstitial tissues. Some CD4 + and CD8 $+\mathrm{T}$ cells were localized in the lumen of efferent ductules and epididymal duct. No significant difference was observed in the frequencies between CD4 + and CD8 $+\mathrm{T}$ cells in each tissue. The Bu1 $+\mathrm{B}$ cells were observed in the testicular and epididymal interstitial tissues at a low frequency. These results suggest that in the testis and epididymis immunodefense system to pathogens are formed primarily by $\mathrm{T}$ cells. Cell-mediated immunoresponse to sperm may occur in the ductules of the epididymis, whereas induction of auto-antibodies to sperm may be prevented because of a low population of B cells and possibly by the regulation of $\mathrm{CD} 8+\mathrm{T}$ cells.
\end{abstract}

Key words : testis, epididymis, $\mathrm{T}$ cells, B cells, roosters

\section{Introduction}

The testis, epididymis and ductus deference are located in the abdominal cavity in birds. The testis consists of numerous seminiferous tubules containing germ cells and Sertoli cells that form blood-testis barrier, narrow interstitial tissue and tunica albuginea covering the surface of testis. The seminiferous tubules connect with the rete testis, which drains to the ductus system in epididymis, namely the efferent ductules and epididymal duct (Kirby and Froman, 2000). The male reproductive organs are the site that may be infected by pathogenic microorganisms such as avian leukosis virus (Afanassieff et al., 1996), herpesvirus (Benfield and Adldinger, 1984), mycoplasma (Pruthi and Kharole, 1981), and bronchitis virus (Mahecha et al., 2002). In the epididymis, sperm and germ cells detached from the seminiferous epithelium were phagocytosed by mucosal epithelial cells and macrophages, suggesting that degraded germ cells and unejaculated sperm in male genital tract are absorbed by them (Tingari and Lake, 1972 ; Hess and Thurston, 1977 ; Nakai et al., 1989 ; Nakai and Nasu, 1991

Received : May 13, 2004, Accepted : July 14, 2004

Correspondence to : Y. Yoshimura, Graduate School of Biosphere Science, Higashi-Hiroshima 7398528, Japan. TEL \& FAX : +81-824-24-7958 E-mail : yyosimu@hiroshima-u.ac.jp 
b). On the other hand if the immune functions are imbalanced, the immune response to germ cells and spermatozoa may cause reproductive disorder to decrease fertility as suggested in mammals (Peters and Coulam, 1992 ; Diekman et al., 2000). Thus the immune system plays significant roles in defense to pathogens and also may affect the reproductive functions. However, distribution of lymphocyte subsets in male genital organs remains to be examined in birds. The $\mathrm{T}$ cell subsets play essential role in cell-mediated immune response. Helper/inducer T cells express CD4 antigen on their surface, whereas cytotoxic/suppressor T cells do CD8 antigen (Chen et al., 1994). The $\mathrm{B}$ cells, which develops to plasma cells producing antibodies, express $\mathrm{Bu} 1$ antigen on their surface (Veromaa et al., 1988). The goal of this study was to localize the T cell subsets and B cells in the testis and epididymis of roosters. They were identified by immunocytochemistry for surface antigens of those lymphocytes.

\section{Materials and Methods}

\section{Birds and tissue preparation}

White Leghorn male birds (approximately 600-d-old) were kept in individual cages under a light regimen of $14 \mathrm{~h}$ light and $10 \mathrm{~h}$ dark, and provided with feed and water ad libitum. The testis was collected together with epididymis after euthanization of birds by decapitation $(n=5)$. The tissues of left organs were embedded in cryo-embedding medium (Sakura Co., Tokyo, Japan) and snap-frozen in isopentane and solid $\mathrm{CO}_{2}$ mixture. Frozen sections of them were air-dried on slides and fixed with acetone on ice for $10 \mathrm{~min}$. Then the sections were immunostained for $\mathrm{T}$ cell subsets and $\mathrm{B}$ cells as described previously (Zheng and Yoshimura, 2001). Briefly, sections were incubated with mouse monoclonal antibodies to chicken CD4 or CD8 (Southern Biotech Associates Inc., Birmingham, USA) or Bu1 (Veromaa et al., 1988) diluted to $1: 100$ in phosphate buffered saline (PBS) containing $1 \%(\mathrm{w} / \mathrm{v})$ bovine serum albumin for $2 \mathrm{~h}$, followed by washing with PBS for $15 \mathrm{~min}(5 \times 3$ times). Then the immunoreaction products were identified using Histofine SAB-PO (M) kit (Nichirei Co., Tokyo, Japan), namely sections were incubated with biotinylated anti-mouse $\operatorname{IgG}+\operatorname{IgM}+\operatorname{IgA}$, and avidin-peroxidase complex for $1 \mathrm{~h}$ each. The immunoreaction products were visualized by incubating the sections with a reaction mixture consisting of $0.02 \%$ (w/v) $3,3^{\prime}$ diaminobenzidine tetrahydrochloride and $0.005 \%$ (v/v) $\mathrm{H}_{2} \mathrm{O}_{2}$ in $0.05 \mathrm{M}$ Tris- $\mathrm{HCl}$ buffer, $\mathrm{pH}$ 7.6. Then the sections were counterstained with hematoxylin, dehydrated and covered. For the control staining the first antibodies were replaced with normal mouse IgG (Funakoshi Co., Tokyo, Japan), and no specific staining was observed.

Observations and counting of cell number

The sections were examined under a light microscope with image analysis software (Image-Pro Plus, Media Cybemetics, Silver Spring, MD, USA). Counting of the CD4 + and CD8 + cells was performed in the interstitial tissue of testis, in the subepithelial layer of efferent ductules and epididymal ducts (subepithelial stroma and fibromuscular layer) and in the epididymal interstitial tissue. Two sections were examined in one tissue of a bird, and more than two different regions were analyzed on one section. The mean of the counts was expressed as the number of cells in $5 \times 10^{4} \mu \mathrm{m}^{2}$ tissue in one 
tissue of a bird. Bu1 + cell population was not analyzed because the population was not enough to count accurately.

Statistical analysis

The significance of differences between the frequencies of CD4 + and CD8 $+\mathrm{T}$ cells within each tissue and between those of efferent ductules and epididymal ducts within CD4 + or CD8 $+\mathrm{T}$ cells was examined by Student's t-test. $\mathbf{P}<0.05$ was considered significant.

\section{Results}

The seminiferous epithelium was well developed with spermatogenic features, and the area of interstitial connective tissue was narrow and contained interstitial cells. Both CD4 + and CD8 $+\mathrm{T}$ cells were located in the interstitial tissues (Fig. $1 \mathrm{a}, \mathrm{b}$ ). There was no significant difference in the frequency between CD4 + and CD8 $+\mathrm{T}$ cells in the interstitial tissue (Fig. 2). The population of Bu1 + B cells was extremely low in the testis (Fig. 1 c).

In the epididymis the efferent ductules and epididymal duct were well developed. The efferent ductules formed many folds and were lined with cilliated pseudostratified epithelium. The mucosal surface of epididymal duct was lined with non-ciliated epithelium. The efferent ductules and epididymal duct were surrounded by thin fibromuscular layer. The interstitial tissue between each ductule consisted of the loose connective tissue. Many of the CD4 + and $\mathrm{CD} 8+\mathrm{T}$ cells were localized in the subepithelial layer of efferent ductules and epididymal duct (Fig. $1 \mathrm{~d}$, e). No significant difference in the frequencies was observed between the CD4 + and CD8 $+\mathrm{T}$ cells within efferent ductules or epididymal ducts as well as between the efferent ductules and epididymal ducts within each of $\mathrm{T}$ cell subsets (Fig. 2). The interstitial tissue between the ductules was also the site where both $\mathrm{T}$ cell subsets were distributed (Fig. $1 \mathrm{~d}$, e), and the frequencies were almost equal between CD4 + and CD8 $+\mathrm{T}$ cells (Fig. 2). Some CD4 + and CD8 $+\mathrm{T}$ cells were localized in the lumen of efferent ductules and epididymal duct (Fig. 1d, e). Low populations of Bu1 + B cells were found in the subepithelial layer and interstitial tissue (Fig. 1f).

\section{Discussion}

This is the first report that identified the lymphocyte subsets in the testis and epididymis of roosters. The significant findings were : (1) the CD4 + and CD8 $+\mathrm{T}$ cells were identified in the interstitial tissue of testis, in the wall of ductus system and interstitial tissue of epididymis, and occasionally in the lumen of ductules of epididymis, and (2) the population of $\mathrm{Bu} 1+\mathrm{B}$ cells was very low in both testis and epididymis.

Previous histological studies reported that intra-epithelial lymphocytes were identified in the excurrent ducts of the testis of roosters (Aire and Malmquist, 1979 ; Stefanini et al., 1999). The current study identified the types of the lymphocytes by immunocytochemistry for surface antigens of them. The CD4 + and CD8 $+\mathrm{T}$ cells were distributed in both testis and epididymis tissues, whereas the population of $\mathrm{Bu} 1+$ $\mathrm{B}$ cells was low. One of the roles of these lymphocytes may be to form the defense 

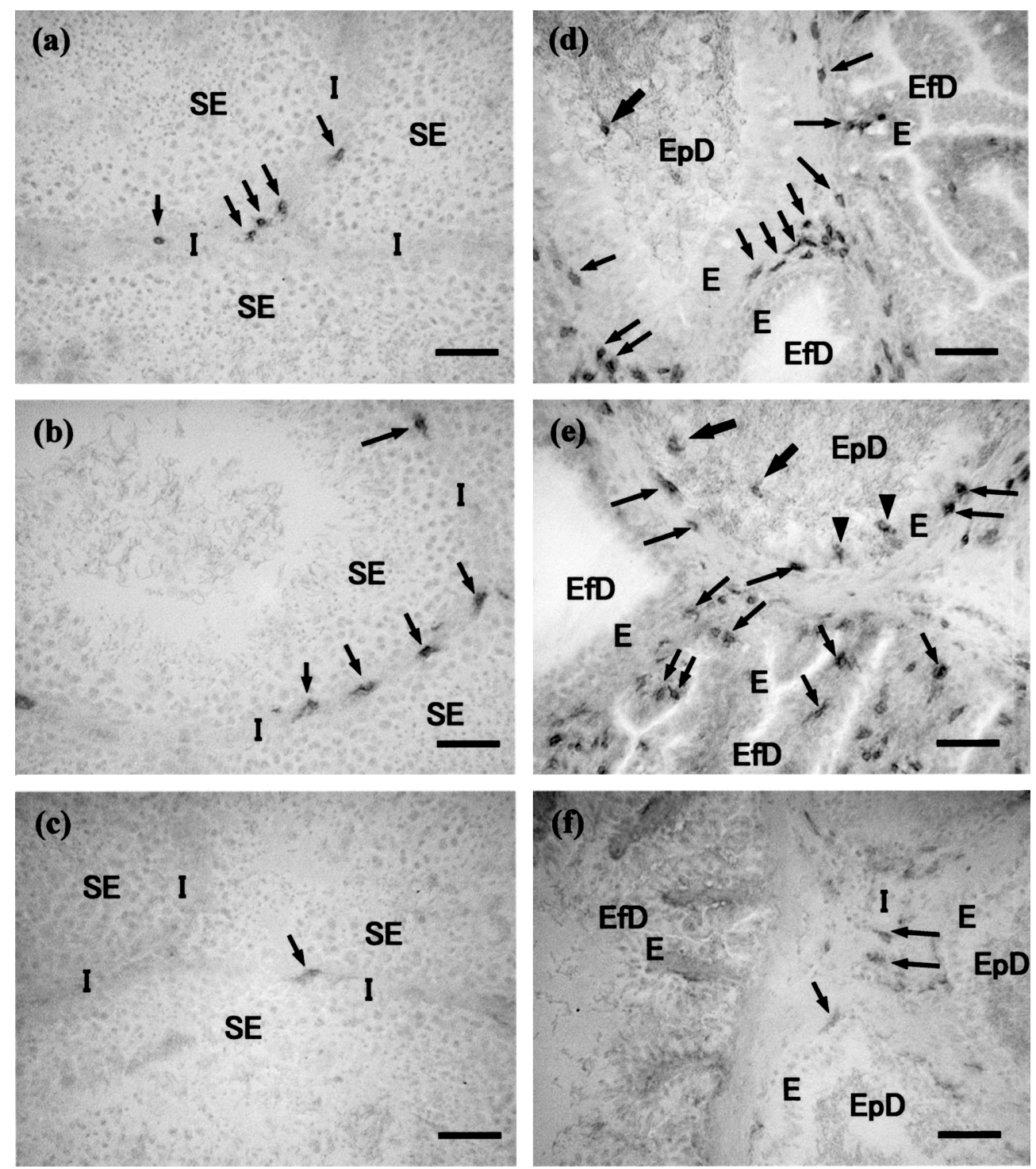

Fig. 1. Immunolocalization of $\mathrm{T}$ cells and $\mathrm{B}$ cells in the testis and epididymis of roosters.

(a), (b) and (c) show the sections of testis immunostained for CD4, CD8 and $\mathrm{Bu} 1$, respectively. The CD4-positive and CD8-positive cells are located in the testicular interstitial tissue. A Bu1-positive cell is observed in the interstitial tissue. (d), (e) and (f) show sections of epididymis immunostained for CD4, CD8 and Bu1, respectively. The CD4-positive and CD8-positive cells are located mainly in the subepithelial layer. Note the CD4-positive and CD8positive cells in the semen within epididymal ducts (large arrows). Arrow heads indicate the CD8-positive cells in the mucosal epithelium. A relatively low population of Bul-positive cells is observed in the subepithelial layer. Small arrows indicate examples of positive cells. $\mathrm{E}=$ mucosal epithelium, $\mathrm{EfD}=$ efferent ductus, $\mathrm{EpD}=$ epididymal duct, $\mathrm{I}=$ interstitial tissue, $\mathrm{SE}=$ seminiferous epithelium. Scale bar $=45 \mu \mathrm{m}$. 


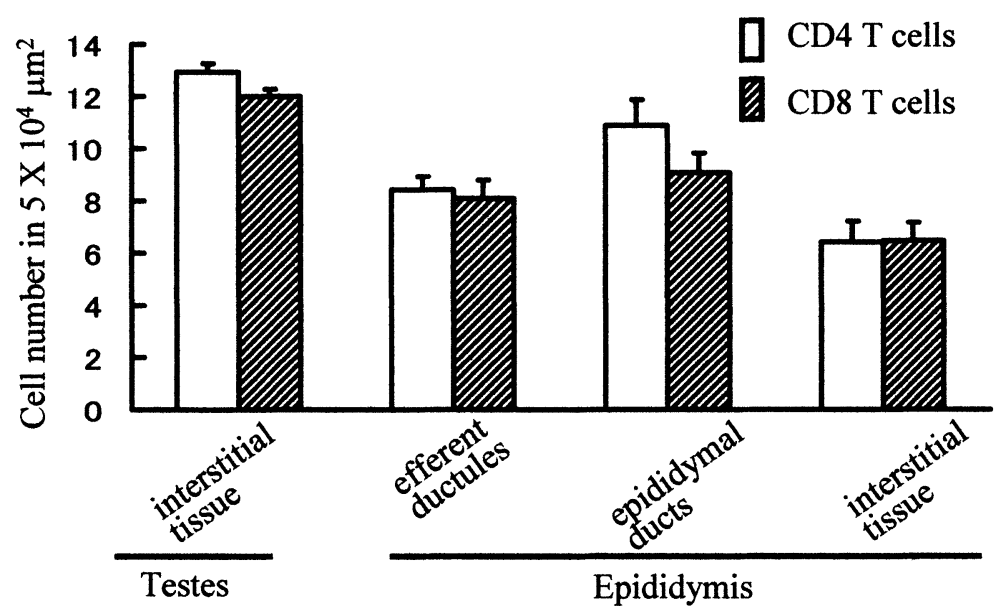

Fig. 2. Frequencies of CD4-positive and CD8-positive cells in the testis and epididymis of roosters.

Values are mean \pm SEM of positive cell number in $5 \times 10^{4} \mu \mathrm{m}^{2}(\mathrm{n}=5)$.

system against pathogenic agents. The male reproductive organs are the infectious tissues of some pathogenic microorganisms (Afanassieff et al., 1996 ; Benfield and Adldinger, 1984 ; Pruthi and Kharole, 1981 ; Mahecha et al., 2002). A high frequency of $\mathrm{T}$ cell subsets suggests that the primary defense system is formed by the cell-mediated immunity in the testis and eipididymis of healthy roosters. The testicular interstitial tissue and subepithelial layer of ductules in the epididymis may be the major tissue for the defense system in the testis and epididymis, respectively, because many CD4 + and $\mathrm{CD} 8+\mathrm{T}$ cells were located in these tissues.

The CD4 + and CD8 $+\mathrm{T}$ cells were identified in the lumen of seminiferous tubules and ductules of the epididymis. The mucosal epithelial cells of ductules in the epididymis formed the tight junctions, which plays a role in the barrier system to restrict the diffusion of blood components into tubules (Nakai and Nasu, 1991 a). The influx of $\mathrm{T}$ cells into the lumen suggests that the barrier system may not be complete to prevent the passage of the lymphocytes into the lumen even in healthy birds. Also, T cells may enter the lumen of ductus efference and epididymal duct through the mucosal epithelium which contained intra-epithelial $\mathrm{T}$ cells. The presence of $\mathrm{T}$ cells in the lumen of epididymal ductules suggests that some cell-mediated immune response to spermatozoa may occur in healthy birds. There are reports that unejaculated sperm were phagocytosed by macrophages (Nakai et al., 1989 ; Nakai and Nasu, 1991 b) and mucosal epithelium of the testicular excurrent ducts (Tingari and Lake, 1972 ; Hess and Thurston, 1977 ; Aire, 2000). There may be an interaction between CD4 + T cells and macrophages for the response to sperm because macrophage activities were enhanced by CD4 $+\mathrm{T}$ cells (Lillehoj and Okamura, 2003).

If the autoantibodies to sperm are synthesized by B cells, the fertility of the birds may be declined. Froman et al. (1990) suggested that spermatozoal degeneration tends to be latent at the semen production, but it may not due to spermatozoal autoimmunity 
because they failed to reveal $\operatorname{IgY}$ and $\operatorname{IgA}$ associated with spermatozoa in low fertility roosters. However, Kirby et al. (1992) suggested a reduction in fertility may result from the increase of sperm antibodies because immunization of male birds with spermatozoa resulted in a reduction of fertility in male birds. Decline of fertility due to autoimmunity to spermatozoa have been suggested also in mammals (Peters and Coulam, 1992 ; Diekman et al., 2000). The current results indicated that the frequency of B cells was low in both testis and epididymis. Also, some members of CD8 $+\mathrm{T}$ cells may be suppressor $\mathrm{T}$ cells that reduce the antibody production by $\mathrm{B}$ cells. Thus, it is assumed that lower frequency of B cells and suppressive effects of CD8 $+\mathrm{T}$ cells on B cells are responsible for the inhibition of the anti-sperm autoantibody induction in roosters. In mammals also immunocytochemical studies have shown the distribution of immune cells including helper $\mathrm{T}$ cells, cytotoxic $\mathrm{T}$ cells and monocytes-macrophages in the epididymis (El-Demiry et al., 1985 ; Flickinger et al., 1997 ; Serre and Robaire, 1999). Furthermore, it is also suggested that in healthy animals the epididymis is not a site for local immunoglobulin synthesis (Flickinger et al., 1997) and cytotoxic T cells may contribute to immunological barrier preventing immune response to spermatozoa in testicular excurrent duct (Yakirevich et al., 2002). Furthermore, the immunosuppressive components for protection of sperm cells from immune cells may also be secreted by epididymis in mammals (Dostal et al., 1997).

In conclusion, we suggest that in the testis and epididymis the immunodefense system is formed by lymphocytes with a greater population of $\mathrm{T}$ cells than $\mathrm{B}$ cells. Cell-mediated immunoresponse to sperm may occur in the ductules of epididymis, but induction of anti-sperm antibody may be prevented by a lower frequency of B cells and suppressive effects of CD8 $+\mathrm{T}$ cells.

\section{Acknowledgement}

This work was supported in part by Grant-in-Aid for Scientific Research from Ministry of Education, Culture, Sports, Science and Technology, Japan.

\section{References}

Afanassieff M, Dambrine G, Ronfort C, Lasserre F, Coudert F and Verdier G. Intratesticular inoculation of avian leukosis virus (ALV) in chickens : production of neutralizing antibodies and lack of virus shedding into semen. Avian Diseases, $40: 841-852.1996$.

Aire TA. Active spermiophagy in the initial part of the proximal efferent duct of the epididymis of normal domestic fowl (Gallus domesticus). Research in Veterinary Science, 68 : 135-140. 2000.

Aire TA and Malmquist M. Intraepithelial lymphocytes in the excurrent ducts of the testis of the domestic fowl (Gullus demesticus). Acta anatomica, 103:142-149. 1979.

Benfield DA and Adldinger HK. Latent herpesvirus infection of testes and spinal ganglia of turkeys with semen abnormalities. Archives of Virology, 82 : 195-209. 1984.

Chen CH, Gobel TWF, Kubota T and Cooper MD. T cell development in the chicken. Poultry Science, 73 : 1012-1018. 1994.

Diekman AB, Norton EJ, Westbrook VA, Klotz KL, Naaby-Hansen S and Herr JC. Anti-sperm antibodies from infertile patients and their cognate sperm antigens : a review. Identity between SAGA-1, the H6-3C4 antigen, and CD52. American Journal of Reproductive Immunology, $43: 134-143.2000$. 
Dostal J, Veselsky L, Marounek M, Zelezna B and Jonakova V. Inhibition of bacterial and boar epididymal sperm immunogenicity by boar seminal immunosuppressive component in mice. Journal of Reproduction and Fertility, 111 : 135-141. 1997.

El-Demiry MI, Hargreave TB, Busuttil A, James K, Ritchie AW and Chisholm GD. Lymphocyte sub-populations in the male genital tract. British Journal of Urology, 57 : 769-774. 1985.

Flickinger CJ, Bush LA, Howards SS and Herr JC. Distribution of leukocytes in the epithelium and interstitium of four regions of the Lewis rat epididymis. Anatomical Record, $248: 380^{-}$ 390. 1997.

Froman DP, Kirby JD, Lawler RM and Bernier PE. Onset of spermatozoal degeneration in low-fertility Delaware roosters and test for autoimmune basis. Journal of Andrology, 11 : 113-119. 1990.

Hess RA and Thurston RJ. Ultrastructure of epithelial cells in the epididymal region of the turkey (Meleagris gallopavo). Journal of Anatomy, 124 : 765-778. 1977.

Kirby JD, Classen HL, Smyth JR Jr and Froman DP. Induction of immunity to spermatozoa in male domestic fowl and effects on fertility. Journal of Reproduction and Fertility, 95 : 7986. 1992.

Kirby JD and Froman DP. Reproduction in male birds. In : Sturkie's Avian Physiology (Whittow GG ed.). $4^{\text {th }}$ ed. pp. 597-615. Academic Press. London. 2000.

Lillehoj $\mathrm{H}$ and Okamura $\mathrm{M}$. Host immunity and vaccine development of coccidia and salmonella infections in chickens. Journal of Poultry Science, 40 : 151-193. 2003.

Mahecha GA, Oliveira CA, Balzuweit K and Hess RA. Epididymal lithiasis in roosters and efferent ductule and testicular damage. Reproduction, 124:821-834. 2002.

Nakai M, Hashimoto Y, Kitagawa H, Kon Y and Kudo N. Histological study on seminal plasma absorption and spermiophagy in the epididymal region of domestic fowl. Poultry Sceince, $68: 582-589.1989$.

Nakai $\mathrm{M}$ and Nasu T. Ultrastructural study on junctional complexes of the excurrent duct epithelia in the epididymal region in the fowl. Journal of Veterinary Medical Science, 53 : 677-681. $1991 \mathrm{a}$.

Nakai $\mathrm{M}$ and Nasu T. Macrophages in the rete testis of pubertal male fowl. Journal of Veterinary Medical Science, 53 : 727-728. $1991 \mathrm{~b}$.

Peters AJ and Coulam CB. Sperm antibodies. American Journal of Reproductive Immunology, $27: 156-162.1992$.

Pruthi AK and Kharole MU. Sequential pathology of genital tract in chickens experimentally infected with Mycoplasma gallisepticum. Avian Diseases, 25 : 768-778. 1981.

Serre V and Robaire B. Distribution of immune cells in the epididymis of the aging Brown Norway rat is segment-specific and related to the luminal content. Biology of Reproduction, $61: 705-714.1999$.

Stefanini MA, Orsi AM, Gregorio EA, Viotto MJ and Baraldi-Artoni SM. Morphologic study of the efferent ductules of the pigeon (Columba livia). Journal of Morphology, 242 : 245-255. 1999.

Tingari MD and Lake PE. Ultrastructural evidence for resorption of spermatozoa and testicular fluid in the excurrent ducts of the testis of the domestic fowl, Gallus domesticus. Journal of Reproduction and Fertility, $31: 373-381.1972$.

Veromaa T, Vainio O, Eerola E and Toivanen P. Monoclonal antibodies against chicken Bu-1a and $\mathrm{Bu}-1 \mathrm{~b}$ alloantigens. Hybridoma, $7: 41-48.1988$.

Yakirevich E, Yanai O, Sova Y, Sabo E, Stein A, Hiss J and Resnick MB. Cytotoxic phenotype of intra-epithelial lymphocytes in normal and cryptorchid human testicular excurrent ducts. Human Reproduction, 17 :275-283. 2002.

Zheng WM and Yoshimura Y. Organ-specificity of estrogen effects on the induction of immunocompetent cells in the chicken. Journal of Poultry Science, $38: 41-49.2001$. 